\title{
Antimicrobial susceptibility profile and research of mecA and erm genes in coagulase-negative staphylococci isolated from platelet concentrates bags
}

\author{
Rosiéli Martini', Rosmari Hörner ${ }^{1, *}$, Daniel Ângelo Sganzerla Graichen²
}

${ }^{1}$ Laboratory of Bacteriology and Department of Clinical and Toxicology Analysis, Federal University of Santa Maria, Rio Grande do Sul, RS, Brazil, ${ }^{2}$ Laboratory of Evolutionary Genetics of Centro de Educação Superior Norte, CESNORS, Palmeira das Missões, RS, Brazil

\begin{abstract}
In recent years, several studies have described the clinical impact of bacterial infection associated with transfusion of platelet concentrates (PCs). Among the blood components, PCs are responsible for the highest rates of bacterial contamination as well as septic transfusion reactions. We assessed antimicrobial susceptibility profile, resistance to methicillin (MRCoNS), and resistance to macrolides, lincosamides and streptogramins of group $\mathrm{B}\left(\mathrm{MLS}_{\mathrm{B}}\right)$ of 16 coagulase-negative staphylococci (CoNS) isolates from an investigation in 691 PCs bags. We then compared conventional and automated phenotypic methods, disc diffusion test (DD) and VITEK ${ }^{\circledR} 2$, respectively as well as phenotypic and genotypic methods (Polymerase Chain Reaction - PCR). All CoNS were susceptible to vancomycin. The disc diffusion test characterized $18.75 \%$ as MRCoNS and $37.5 \%$ with inducible resistance to MLS $_{\mathrm{B}}\left(\mathrm{iMLS}_{\mathrm{B}}\right)$, and with VITEK ${ }^{\circledR} 2,6.3 \%$ and $31.25 \%$, respectively. The mecA gene was detected in $18.75 \%$ and the erm gene in $31.25 \%$ of the isolates. In this study, we found equal percentage values between presence of the mecA gene by PCR and resistance to methicillin using cefoxitin by DD test, evidence of the erm gene by PCR, and iMLS $_{B}$ resistance by automation (VITEK ${ }^{\circledR} 2$ ). Moreover, we identified three strains with beta-lactamase overproduction, and the occurrence of a bigger mistake was verified when automation was compared with DD test. And we observed that D-test was the most reliable for the detection of $\mathrm{iMLS}_{\mathrm{B}}$ resistance in Staphylococcus sp.
\end{abstract}

Uniterms: Bacterial resistance. Staphylococcus sp. Platelet concentrates. MecA. Erm.

\section{INTRODUCTION}

Bacterial contamination of blood components has probably been the first disease transmitted by transfusion (Blajchman, 1995). Despite bacterial sepsis associated to transfusion being known for a long time, it remains a serious health problem. Several measures have been deployed to prevent and detect bacterial contamination of platelet concentrates (PCs). These actions have reduced but not eliminated the risk of septic transfusion reactions (Eder, Goldman, 2011). Besides the risk of bacterial contamination of blood components, current studies seek to detect and reduce the risk of transfusion-related acute

*Correspondence: Rosmari Horner. Laboratório de Bacteriologia. Departamento de Análises Clínicas e Toxicológicas. Prédio 26, Sala 1201 - Campus da UFSM. Universidade Federal de Santa Maria - 97015-900 - Santa Maria - RS, Brasil. E-mail: rosmari.ufsm@gmail.com lung injury (TRALI), a syndrome characterized by acute respiratory distress following transfusion (Eder, Dy, O’Neill, 2016).

PCs are blood components with the highest bacterial contamination rate and usually responsible for most of septic transfusion reactions (Chang et al., 2004). This type of bacterial contamination due to PCs infusion is much higher than other types of transfusion-transmitted infections (Jacobs, Palavecino, Yomtovian, 2001; Goodnough, Sander, Brecher, 2003; Vasconcelos et al., 2004).

Gram-positive cocci are the most common contaminants in PCs and coagulase-negative staphylococci (CoNS) are the main responsible for septic transfusion reactions (Greco et al., 2008). They are frequently associated with hospital infections, particularly in immunocompromised patients (Stoll et al., 2002). 
Although CoNS form part of the normal flora of humans, they are acknowledged as important pathogens, causing a wide variety of infections. They are isolated from skin and soft tissue infections, respiratory and lower urinary tract, and specifically bloodstream infections (Landrum et al., 2012).

In recent years, due to the high rate of hospital infections associated with antimicrobial resistance, resistance patterns of CoNS have become the study source of many researchers worldwide (De Giusti et al., 1999).

The classic mechanism of resistance to methicillin present in CoNS (coagulase-negative staphylococci resistant to methicillin - MRCoNS), encoded by the $m e c \mathrm{~A}$ gene is well documented, conferring resistance to all beta-lactam agents. Studies show that there has been a substantial increase in MRCoNS isolation rates in hospital infections, including Brazil, where resistance rates are among $50-80 \%$, varying according to bacterial species and patient's demographic data (Marshall et al., 1998; Hussain et al., 2000; Ferreira et al., 2003; Palazzo, Darini, 2006).

CoNS may also be resistant to macrolides, lincosamides and streptogramins of group $B$ agents $\left(\mathrm{MLS}_{\mathrm{B}}\right)$, which may be constitutive $\left(\mathrm{cMLS}_{\mathrm{B}}\right)$ or inducible $\left(\mathrm{iMLS}_{\mathrm{B}}\right)$. In the constitutive expression, resistance to erythromycin and clindamycin is detected in a normal antibiogram. However, in the inducible form, resistance to erythromycin and false susceptibility to clindamycin are detected. It is recommended that the conventional phenotypic detection of $\mathrm{iMLS}_{\mathrm{B}}$ resistance is performed by D-test (Clinical and Laboratory Standards Institute, 2014). There are three mechanisms of Staphylococcus resistance linked to the $\mathrm{MLS}_{\mathrm{B}}$ group: target modification of ribosomes by methylase, mediated by erm genes (Nakajima, 1999); efflux mechanisms mediated by msrA gene (Matsuoka et al., 1999) and characterized as $\mathrm{MS}_{\mathrm{B}}$ phenotype, conferring resistance to macrolides only (Matsuoka et al., 2002; David, Pimentel, Freire, 2005); and antibiotics enzymatic inactivation (Roberts et al., 1999). Nevertheless, the predominant form is target modification (Roberts et al., 1999; Leclercq, 2002).

A study published by our research group emphasizes the importance of recognizing sepsis caused by contaminated PCs transfusion, specifically in immunocompromised patients, since bacterial sepsis associated to platelet transfusion is nowadays the most common infectious complication of transfusion medicine (Martini et al., 2012).

The aim of this study was to assess the susceptibility profile against antimicrobials as well as to research the typical resistance to methicillin and to $\mathrm{MLS}_{\mathrm{B}}$ group by phenotypic, conventional and automation methods, including $m e c \mathrm{~A}$ and erm genes.

\section{MATERIAL AND METHODS}

\section{Inclusion criteria for isolated bacterial and reference standard strains}

A total of 16 CoNS were isolated through a study on bacterial investigation carried out in 691 PCs bags, collected during 2009/2010, from the Blood Bank of the city of Santa Maria, Rio Grande do Sul State (HEMORGS/ SM, RS),

The following strains of international reference standard (American Type Culture Collection - ATCC) were used as controls in genotypic and phenotypic tests: Staphylococcus aureus ATCC 43300, ATCC 25923, BAA977, BAA976 and ATCC 29213.

\section{Antimicrobial Susceptibility Testing by disk diffusion test (DD) and VITEK $® 2$; and determination of minimum inhibitory concentration (MIC) of vancomycin}

For the performance of phenotypic tests, strains previously stored in Trypticase Soy Broth 15\% glycerol were activated in Mueller Hinton agar and incubated at $35 \pm 2{ }^{\circ} \mathrm{C}$ for 24 hours.

We performed antimicrobial susceptibility testing using two methods, the conventional method of disk diffusion (DD) and the automated method VITEK ${ }^{\circledR}$ 2. Antimicrobial susceptibility testing was performed using disk diffusion test (DD) following the cutoff points recommended by the Clinical and Laboratory Standards Institute (Clinical and Laboratory Standards Institute, 2014), and susceptibility testing was performed by VITEK ${ }^{\circledR} 2$ automated method, according to the manufacturer's standards (bioMérieux). Vancomycin minimum inhibitory concentration (MIC) was made by the broth micro-dilution method, performed in duplicate (Clinical and Laboratory Standards Institute, 2014).

\section{Analysis of resistance genes}

For the genotypic testing, deoxyribonucleic acid extraction (DNA) was carried out by heating shock. Bacterial isolates were grown on Trypticase Soy Agar and then incubated at $35 \pm 2{ }^{\circ} \mathrm{C}$ for 18 to 24 hours. Subsequently, a dense bacterial suspension with 4-5 isolated colonies was prepared in an Eppendorff type microtube containing $500 \mathrm{uL}$ autoclaved Milli Q water. This suspension was homogenized by vortex and placed in water bath at $100{ }^{\circ} \mathrm{C}$ for 15 minutes. The microtube was subjected to heating shock (on ice) for 5 minutes 
and centrifuged at 11,000 rotations per minute (rpm) for 20 minutes. The supernatant (containing the DNA) was transferred to another microtube which was frozen at -20 ${ }^{\circ} \mathrm{C}$ (Nogueira et al., 2004; Freschi, Carvalho, Oliveira, 2005; Scheffer, 2008; Aguilar, 2009). DNA extraction by heating shock was confirmed by the 16S rRNA gene amplification, obtaining a high quality DNA.

\section{Amplification of $16 \mathrm{~S}$ ribosomal RNA (rRNA)}

The extracted DNA was subjected to electrophoresis in $1.0 \%$ agarose gel to verify DNA presence in the extracted material. The $16 \mathrm{~S}$ rRNA was amplified by Polymerase Chain Reaction (PCR) and the following primers were used: 5'-GTAGTCCACGCCGTAAAC-3' and 5'-TAAACCACATGCTCCACC-3 (Li et al., 2009).

\section{Identification of MRCoNS}

Identification of bacterial species isolated from infected PCs bags was performed by VITEK ${ }^{\circledR} 2$ automated system. To study phenotypic resistance to methicillin were used discs of cefoxitin $(30 \mu \mathrm{g})$ and MIC cefoxitin (VITEK ${ }^{\circledR} 2$ ). Results were interpreted according to the criteria established by the CLSI (Clinical and Laboratory Standards Institute, 2014).

To identify the presence of mecA gene, the following sequences were used: mecA_F AGT TAG ATT GGG ATC ATA GCG and mecA_R CGA TGC CTA TCT CAT ATG CTG (Ludwig Biotec ${ }^{\circledR}$ ). The primers used for mecA gene testing were designed using the $\mathrm{PBP} 2$ a protein structure made in the Laboratory of Molecular Biology and Sequencing - LabDros (Lim, Strynadka, 2002). The best mold region for primer design is the non-variable portion of PBP $2 \mathrm{a}$ - between 27 and 326 amino acids - being in base pairs, corresponding to the region between 81 and 978 nucleotides. The GU301106 reference sequence from GenBank was used as the primer's choice. The size of amplicons generated by the amplification using these primers is $145 \mathrm{bp}$, and they were checked in $0.8 \%$ agarose gel. MRCoNS identification was followed as suggested by Kearns et al. (1999).

\section{Detection of macrolide-lincosamide- streptogramin $B\left(\mathrm{MLS}_{\mathrm{B}}\right)$ resistance}

Double disk or Diffusion Test (D-test) was performed using the DD technique, following the standards recommended by the CLSI (Clinical and Laboratory Standards Institute, 2014). erm ABC genes determination was carried out according to Coutinho et al. (2010)
Primers' sequence was: ermA_F 5'-GTT CAA GAA CAA TCA ATA CAG AG-3' and ermA_R 5'-GGA TCA GGA AAA GGA CAT TTT AC-3'; ermB_F 5'-CCG TTT ACG AAA TTG GAA CAG GTA AAG GGC-3' and ermB_R '5-GAA TCG AGA CTT GAG TGT GC-3'; ermC_F 5'GCT AAT ATT GTT TAA ATC GTC AAT TCC- $-\overline{3}$ ' and ermC_R 5'-GGA TCA GGAAAA GGA CAT TTT AC-3'.

\section{Statistical analysis}

We proceeded to sensitivity assessment and methods specificity tested in the detection of each resistance mechanism (Bonita, Beaglehole, Kjellström, 2010).

\section{Ethical considerations}

This study was approved by the Research Ethics Committee (CEP) of UFSM under the number 0285.0.243.000-09.

\section{RESULTS AND DISCUSSION}

\section{Automated bacterial identification - VITEK ${ }^{\circledR} 2$}

From the total of 16 isolates of CoNS obtained through a research on bacterial contamination carried out in $691 \mathrm{PCs}$ from HEMORGS/SM, five were identified as Staphylococcus haemolyticus (31.25\%), four as Staphylococcus epidermidis (25\%), four as Staphylococcus warneri (25\%), and three as Staphylococcus saprophyticus $(18.75 \%)$. The bacterial species isolated from contaminated PCs bags were identified by the automated system Vitek ${ }^{\circledR}$ 2. All organisms isolated in contaminated PCs were identified as CoNS, similar to the results found by several authors (Hsueh et al., 2008; Martínez, Tarrand, Lichtiger, 2010; Walther-Wenke et al., 2010). Currently, CoNS represent one of the major nosocomial pathogens and $S$. epidermidis and $S$. haemolyticus are the most significant species. Moreover, the increasing rates of antibiotic resistance are an even greater problem for CoNS than for Staphylococcus aureus, limiting our therapeutic options (Becker, Heilmann, Peters, 2014).

\section{Comparison of susceptibility profile between disk diffusion test (DD) and VITEK ${ }^{\circledR} 2$}

In this study, there was discrepancy in the susceptibility assessment between DD and automation methods with clindamycin, sulfamethoxazole/ trimethoprim, erythromycin, gentamicin and norfloxacin antibiotics (in descending order), and agreement was 
observed only in three (No. 11, 12 and 14) of the 16 analyzed samples as they showed the same profile of antimicrobial susceptibility (Table I).

Studies by other authors confirm our findings when these two methods are compared (VITEK ${ }^{\circledR} 2$ and DD test - considered reference methods), reporting the occurrence of much higher error (VME), higher error (ME), and lowest error (MiE) with the VME prevalence profile (Sapino et al., 2012; Paim, Cantarelli, D'Azevedo, 2014), in susceptibility assessed by the automated method.

All CoNS were resistant to penicillin $G$ and penicillin (automated and DD test, respectively), and by DD test $62.5 \%$ were resistant to clindamycin and erythromycin against $31.25 \%$ and $43.75 \%$, respectively, by automation. Studies have reported CoNS high resistance levels to penicillin, clindamycin and erythromycin (Bernardi, Pizzolitto, Pizzolitto, 2007; Melo et al., 2007; Rigatti et al., 2010). All samples were susceptible to vancomycin, a similar result to that found in the studies mentioned above. In our study vancomycin MIC was between $0.5 \mu \mathrm{g} / \mathrm{mL}$ a $2 \mu \mathrm{g} / \mathrm{mL}$.

\section{Assessment of Methicillin-Resistant Coagulase- Negative Staphylococci (MRCoNS)}

In relation to methicillin resistance in CoNS, three samples $(18.75 \%)$ were resistant to cefoxitin in DD, and by VITEK ${ }^{\circledR} 2$ one sample was resistant (Table II). Regarding CoNS, the standardized tests reporting MRCoNS strains are: agar dilution, DD technique and broth micro-dilution (Clinical and Laboratory Standards Institute, 2014). In the study developed by John et al. (2009), authors showed that, VITEK ${ }^{\circledR} 2$ did not detect methicillin resistance against S. aureus and most of the CoNS. By the PCR method, considered by many authors the gold standard one for the phenotypic testing comparison (Cafiso et al., 2004; Ruzicka et al., 2004; Gad et al., 2009), the mecA gene presence was detected in three samples (18.75\%), which were susceptible to cefoxitin in DD test and VITEK ${ }^{\circledR} 2$ (Table II).

Studies show that methicillin resistance in Staphylococcus occurs mainly due to the production of modified penicillin binding protein (PBP2a) encoded by the mecA gene. This less frequent resistance, however, may also be due to the beta-lactamase overproduction by oxacillin inactivation, resulting in partial hydrolysis of the beta-lactamase ring (borderline resistance to methicillin - BORSA) or the presence of a PBP with low affinity to oxacillin (MODSA) (Tomasz et al., 1989; Ito et al., 2003; Rossi, Andreazzi, 2005). In these last two resistance mechanisms to methicillin, bacteria do not carry the mecA gene (Mohanasoundaram, Lalitha, 2008).
We suggest the identification of three MRCoNS strains with overproduction of beta-lactamase enzyme, which rarely occurs when Staphylococcus strains show resistance in DD test and do not have the mecA gene. The treatment for infections caused by MRCoNS may be performed with linezolid, teicoplanin, and vancomycin, as well as alternative drugs such as macrolides, clindamycin, and trimethoprim/sulfamethoxazole (Rossi, Andreazzi, 2005).

Resistance to methicillin and beta-lactamase overproduction are the main causes of discordant results among phenotypic and genotypic tests to detect MRCoNS (Ghoshal et al., 2004). Research of this kind of resistance by phenotypic methods can be complex due to the heterogeneous expression of many strains, which may also be influenced by growth conditions (Chambers, 1997).

Recent surveys have detected a rare homologous gene to mecA in S. aureus strains isolated from humans and animals with phenotypic resistance to methicillin, found through DD test with cefoxitin, which did not show the mecA gene when specific primers for this gene were used (Cuny et al., 2011; Shore et al., 2011; Cartwright et al., 2013). This gene was initially called ${ }_{\text {mecA }}{ }_{\text {GA251 }}$ and later designated as mec $\mathrm{C}$ (Ito et al., 2012). This mec $\mathrm{C}$ gene has also been reported in CoNS as Staphylococcus stepanovicii, Staphylococcus xylosus and Staphylcoccus scirui (Harrison et al., 2013a, 2013b; Loncaric et al., 2013). As already suggested for the mecA gene, we can probably infer that the origin of the mec $\mathrm{C}$ gene is also among the CoNS (Tsubakishita et al., 2010; Couto et al., 2013). Although mecC gene detection is rare and reported only in Europe so far, this gene is a potential diagnosis problem and triggers several issues for future studies (Paterson, Harrison, Holmes, 2014).

\section{Analysis of macrolide-lincosamide-streptogramin $B\left(\mathrm{MLS}_{\mathrm{B}}\right)$ resistance}

The conventional phenotypic analysis (DD) of resistance to $\mathrm{MLS}_{\mathrm{B}}$ antimicrobials, carried out with the disk approximation test - D-test, characterized six samples $(37.5 \%)$ with inducible (iMLS ${ }_{\mathrm{B}}$ ) and two samples (12.5\%) with constitutive phenotype $\left(\mathrm{cMLS}_{\mathrm{B}}\right)$. On the other hand, the $\mathrm{MS}_{\mathrm{B}}$ phenotype was not detected by DD test (Table III). Coutinho et al. (2010) analysis of CoNS through the DD method found three different phenotypes, distributed as follows: $46.7 \% \mathrm{cMLS}_{\mathrm{B}}$ and $3.3 \%$ of the other two phenotypes (iMLS $\mathrm{B}_{\mathrm{B}}$ and $\mathrm{MS}_{\mathrm{B}}$ ). Through the automated method, our study detected $31.25 \%$ (5 of 16) iMLS $_{\mathrm{B}}$ and $6.25 \%$ (1 of 16$) \mathrm{MS}_{\mathrm{B}}$ (Table III). 


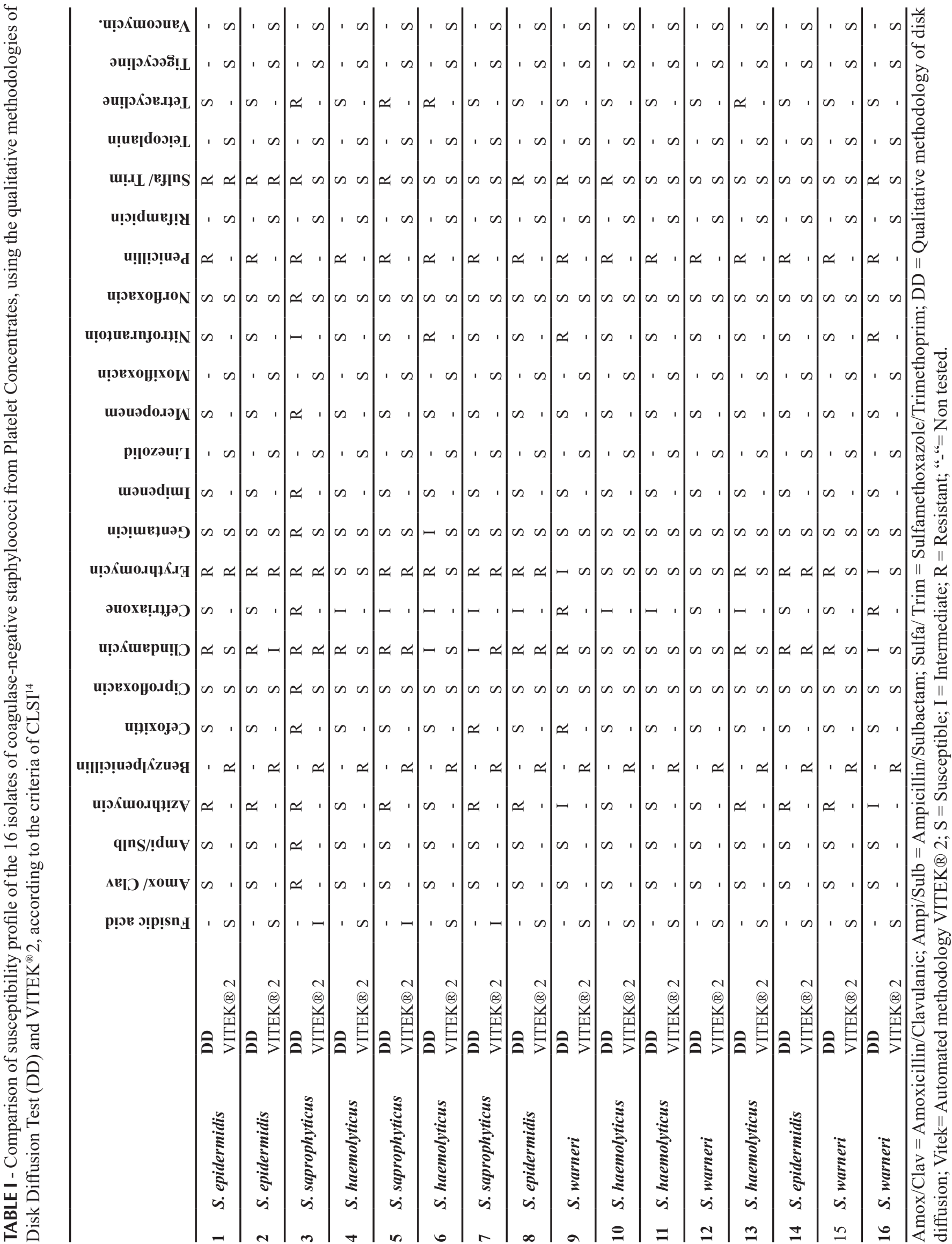


TABLE II - Analysis of MRCoNS of the 16 coagulase-negative staphylococci isolates from Platelet Concentrates through the phenotypic tests of Cefoxitin Disk Diffusion (DD), screening of cefoxitin by VITEK ${ }^{\circledR} 2$, research of the gene mecA by Polymerase Chain Reaction

\begin{tabular}{|c|c|c|c|c|c|c|c|c|c|c|c|c|c|c|c|c|}
\hline Samples & 1 & 2 & 3 & 4 & 5 & 6 & 7 & 8 & 9 & 10 & 11 & 12 & 13 & 14 & 15 & 16 \\
\hline Species & 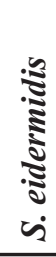 & 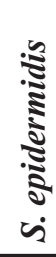 & 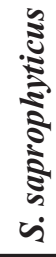 & 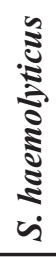 & 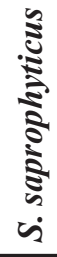 & 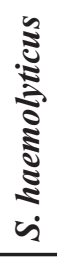 & 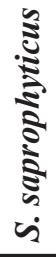 & 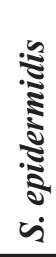 & 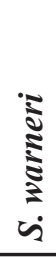 & 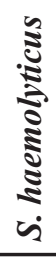 & 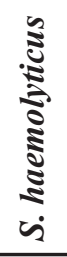 & 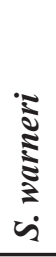 & 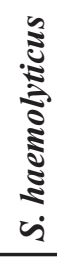 & 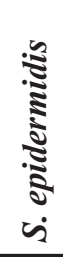 & 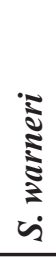 & 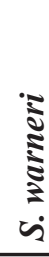 \\
\hline $\mathrm{CFO}$ (DD) & $\mathrm{S}$ & $\mathrm{S}$ & $\mathrm{R}$ & $\mathrm{S}$ & $\mathrm{S}$ & $\mathrm{S}$ & $\mathrm{R}$ & $\mathrm{S}$ & $\mathrm{R}$ & $\mathrm{S}$ & $\mathrm{S}$ & $\mathrm{S}$ & $\mathrm{S}$ & $\mathrm{S}$ & $\mathrm{S}$ & $\mathrm{S}$ \\
\hline $\begin{array}{l}\text { Screening of CFO } \\
\text { (automation) }\end{array}$ & - & - & - & - & - & - & + & - & - & - & - & - & - & - & - & - \\
\hline mecA & - & - & - & - & - & - & - & + & - & - & - & - & - & - & + & + \\
\hline
\end{tabular}

*Research conducted only with strains that showed phenotypic resistance to methicillin; $\mathrm{CFO}=$ Cefoxitin; DD $=$ Qualitative methodology of disk diffusion; $\mathrm{S}=$ Susceptible; $\mathrm{I}=$ Intermediate; $\mathrm{R}=$ Resistant; “_“= absence; “+”= presence.

As mentioned in the paragraph above, no CoNS of our research showed an efflux mechanism ( $\mathrm{MS}_{\mathrm{B}}$ phenotype) by the D-test result. However, when automation was used (VITEK ${ }^{\circledR} 2$ ) one sample showed the $\mathrm{MS}_{\mathrm{B}}$ phenotype: this one showed the iMLS $\mathrm{B}_{\mathrm{B}}$ phenotype by DD test.

The erm gene was detected in five PCR samples $(31.25 \%)$. One (6.25\%) containing ermA gene and four (25\%) erm $\mathrm{C}$ gene; the erm $\mathrm{B}$ gene was not detected in our study. Coutinho et al. (2010) identified the presence of ermA gene in $29.6 \%$ of samples. Regarding the genotypic test, our index showed $67 \%$ of sensitivity and $86 \%$ of specificity, when compared to D-test, which was considered a reference in this study.

Lavallée et al. (2010) compared detection methodologies for iMLS $\mathrm{S}_{\mathrm{B}}$ resistance only, in a collection of 163 Staphylococcus with resistant or intermediate profile to erythromycin and susceptible profile to clindamycin. In our study, through the performance of the same phenotypic tests and erm genes detection by PCR, 93\% and 100\% specificity and sensitivity were found, respectively, for VITEK ${ }^{\circledR} 2$. Therefore, they concluded that automation has failed to detect $\mathrm{iMLS}_{\mathrm{B}}$ resistance in ten strains $(10 / 163)$, resulting in a negative predictive value (NPV) of $74 \%$ (Lavallée et al., 2010). When comparing these same methodologies, in our study we found $73 \%$ of NPV.

The authors cited above concluded that D-test is the most simple and reliable technique to detect this resistance in CoNS strains. They also concluded that agar dilution and VITEK ${ }^{\circledR} 2$ are not as sensitive as D-test within 24 hours for CoNS strains for the detection of iMLS $S_{B}$ (Lavallée et al., 2010).

The discrepancy between results given by the different methods, i.e., inhibition in DD test and gene absence in PCR may be justified by the presence of another gene, erm Y, which was not the subject of this research. However, there are reports of its presence in Staphylococcus (Roberts et al., 1999). The other reason for strains showing the $\mathrm{iMLS}_{\mathrm{B}}$ phenotype that do not contain the erm gene is still not clear (Roberts et al., 1999), but it is attributed to possible changes in the local targets of primers for these genes (Lavallée et al., 2010). Our study confirmed the superiority of D-test when compared to VITEK ${ }^{\circledR} 2$ in $\mathrm{iMLS}_{\mathrm{B}}$ detection.

\section{CONCLUSIONS}

As for resistance genes showed by the different species studied, it was found that one $S$. epidermidis and one $S$. warneri showed the mecA gene and the erm gene. These two species also showed the highest resistance rate to methicillin. Through the antimicrobial susceptibility profile, obtained by the DD technique, approximately $50 \%$ of strains were characterized as multi-drug resistant (MDR), being resistant to more than three classes of antimicrobials.

The results of this study are a reminder to health professionals regarding the CoNS antimicrobial susceptibility profile, since most of them were resistant to antimicrobials (A and B-CLSI ratings) by the conventional assessment method. Also, half of the isolates were resistant to multiple classes of antibiotics, which directly influence on morbidity and mortality, specifically in immunocompromised patients, who often develop infections from resident microorganisms of the skin flora 
TABLE III - Analysis of resistance of the 16 isolates of coagulase-negative staphylococci of Platelet Concentrates against antimicrobials of the MLS class of group B through the phenotypic tests of disk diffusion, screening of inducible/constitutive resistance of clindamycin by VITEK ${ }^{\circledR}$, and the research of the genes erm A, B and C by Polymerase Chain Reaction

\begin{tabular}{|c|c|c|c|c|c|c|c|c|}
\hline Samples & Species & D- Test & $\begin{array}{c}\text { DD } \\
\text { CLI/ERI }\end{array}$ & $\begin{array}{c}\text { Phenotype } \\
\text { DD }\end{array}$ & $\begin{array}{c}\text { Screening } \\
\text { of CLI } \\
\text { (automation) }\end{array}$ & $\operatorname{erm} \mathbf{A}$ & $\operatorname{erm} \mathbf{B}$ & erm $\mathrm{C}$ \\
\hline 1 & S. epidermidis & + & $\mathrm{R} / \mathrm{R}$ & $\mathrm{iMLS}_{\mathrm{B}}$ & $\mathrm{MS}_{\mathrm{B}}$ & - & - & - \\
\hline 2 & S. epidermidis & - & $\mathrm{R} / \mathrm{R}$ & $\mathrm{cMLS}_{\mathrm{B}}$ & - & - & - & - \\
\hline 3 & S. saprophyticus & - & $\mathrm{R} / \mathrm{R}$ & $\mathrm{cMLS}_{\mathrm{B}}$ & $\mathrm{iMLS}_{\mathrm{B}}$ & - & - & - \\
\hline 4 & S. haemolyticus & - & $\mathrm{R} / \mathrm{S}$ & - & - & - & - & - \\
\hline 5 & S. saprophyticus & + & $\mathrm{R} / \mathrm{R}$ & $\mathrm{iMLS}_{\mathrm{B}}$ & $\mathrm{iMLS}_{\mathrm{B}}$ & - & - & - \\
\hline 6 & S. haemolyticus & - & $\mathrm{I} / \mathrm{R}$ & - & - & - & - & - \\
\hline 7 & S. saprophyticus & - & $\mathrm{I} / \mathrm{R}$ & - & $\mathrm{iMLS}_{\mathrm{B}}$ & - & - & - \\
\hline 8 & S. epidermidis & + & $\mathrm{R} / \mathrm{R}$ & $\mathrm{iMLS}_{\mathrm{B}}$ & $\mathrm{iMLS}_{\mathrm{B}}$ & - & - & + \\
\hline 9 & S. warneri & - & $\mathrm{R} / \mathrm{I}$ & - & - & - & - & + \\
\hline 10 & S. haemolyticus & - & $\mathrm{S} / \mathrm{S}$ & - & - & - & - & - \\
\hline 11 & S. haemolyticus & - & $\mathrm{S} / \mathrm{S}$ & - & - & - & - & - \\
\hline 12 & S. warneri & - & $\mathrm{S} / \mathrm{S}$ & - & - & - & - & - \\
\hline 13 & S. haemolyticus & + & $\mathrm{R} / \mathrm{R}$ & $\mathrm{iMLS}_{\mathrm{B}}$ & - & + & - & - \\
\hline 14 & S. epidermidis & + & $\mathrm{R} / \mathrm{R}$ & $\mathrm{iMLS}_{\mathrm{B}}$ & $\mathrm{iMLS}_{\mathrm{B}}$ & - & - & + \\
\hline 15 & S. warneri & + & $\mathrm{R} / \mathrm{R}$ & $\mathrm{iMLS}_{\mathrm{B}}$ & - & - & - & + \\
\hline 16 & S. warneri & - & $\mathrm{I} / \mathrm{I}$ & - & - & - & - & - \\
\hline
\end{tabular}

$\mathrm{S}=$ Susceptible; I = Intermediate; R = Resistant; “_“= absence; “+”= presence; Cli = Clindamycin; Eri = Erythromycin; D-Test Negative $=\operatorname{cMLS}_{\mathrm{B}}$ (resistant to CLI and ERI); D-Test Negative $=\mathrm{MS}_{\mathrm{B}}$ (susceptible CLI and resistant ERI); D-Test Positive = iMLS $_{\mathrm{B}}$ (resistant to CLI and ERI).

such as CoNS. Restrictive policy with antimicrobials as well as immediate and correct prescription should be encouraged in order to control bacterial resistance.

This is in fact the first study conducted in Brazil that investigates susceptibility profile and resistance mechanisms of microorganisms isolated from PCs bags.

\section{ACKNOWLEDGMENTS}

The authors would like to thank the team at the Blood Bank in Santa Maria, Rio Grande do Sul (HEMORGS SM, RS), especially the chemists Zanoni Segala and Viviane Ratzlaff. Also, we would like to thank the chemists at the Microbiology Laboratory of the University Hospital of Santa Maria (HUSM) and the Laboratory of Evolutionary Genetics (GenEvo-CESNORS), especially the biologist Mayza Dalcin Teixeira.

\section{CONFLICT OF INTEREST}

The authors declare there is no conflict of interest.

\section{REFERENCES}

AGUILAR, M.A.P. Caracterização molecular da resistência aos carbapenêmicos em enterobactérias isoladas em hospitais brasileiros. São Paulo, 2009. 133p. Dissertação (Mestrado em Análises Clínicas) - Universidade de São Paulo.

BECKER, K.; HEILMANN, C.; PETERS, G. CoagulaseNegative Staphylococci. Clin. Microbiol. Rev., v.27, p.870926, 2014.

BERNARDI, A.C.A.; PIZZOLITTO, E.L.; PIZZOLITTO, A.C. Detecção da produção de slime por estafilococos coagulasenegativa isolados de cateter venoso central. Rev. Ciênc. Farm. Básica Apl., v.28, p.57-66, 2007.

BLAJCHMAN, M.A. Bacterial contamination of blood products and the value of pre-transfusion testing. Immunol. Invest., v.24, p.163-170, 1995. 
BONITA, R.; BEAGLEHOLE, R.; KJELLSTRÖM, T. Epidemiologia básica. 2.ed. São Paulo: Santos, 2010. cap.6, p.99-114.

CAFISO, V.T.; BERTUCCIO, T.; SANTAGATI, M.; CAMPANILE, F.; AMICOSANTE, G.; PERILLI, M.G.; SELAN, L.; ARTINI, M.; NICOLETTI, G.; STEFANI, $\mathrm{S}$. Presence of the ica operon in clinical isolates of Staphylococcus epidermidis and its role in biofilm production. Clin. Microbiol. Infect., v.10, p.1081-1088, 2004.

CARTWRIGHT, E.J.P.; PATERSON, G.K.; RAVEN, K.E.; HARRISON, E.M.; GOULIOURIS, T.; KEARNS, A.; PICHON, B.; EDWARDS, G.; SKOV, R.L.; LARSEN, A.R.; HOLMES, M.A.; PARKHILL, J.; PEACOCK, S.J.; TÖRÖK, M.E. Use of Vitek 2 antimicrobial susceptibility profile to identify mecC in methicillinresistant Staphylococcus aureus. J. Clin. Microbiol., v.51, p.2732-2734, 2013.

CHAMBERS, H.F. Methicillin resistance in staphylococci: molecular and biochemical basis and clinical implications. Clin. Microbiol. Rev., v.10, p.781-791, 1997.

CHANG, A.H.; KIRSCH, C.M.; MOBASHERY, N.; JOHNSON, N.; LEVITT, L.J. Streptococcus bovis septic shock due to contaminated transfused platelets. Am. J. Hematol., v.77, p.282-286, 2004.

CLINICALAND LABORATORY STANDARDS INSTITUTE. CLSI. Performance standards for antimicrobial susceptibility testing: twenty-fourth Informational Supplement Approved Standard M100-S24. Wayne: CLSI, 2014.

COUTINHO, V.L.S.; PAIVA, R.M.; REITER, K.C.; PARIS, F.; BARTH, A.L.; MACHADO, A.B.M.P. Distribution of erm genes and low prevalence of inducible resistance to clindamycin among staphylococci isolates. Braz. J. Infect. Dis., v.14, p.564-568, 2010.

COUTO, I.; LENCASTRE, H.; SEVERINA, E.; KLOOS, W.; WEBSTER, J.; HUBNER, R.J.; SANCHES, I.S.; TOMASZ, A. Ubiquitous presence of a mecA homologue in natural isolates of Staphylococcus sciuri. Microb. Drug. Resist., v.2, p.377-391, 1996.
CUNY, C.; LAYER, F.; STROMMENGER, B.; WITTE, W. Rare occurrence of methicillin-resistance Staphylococcus aureus $\mathrm{CC} 130$ with a novel mecA homologue in humans in Germany. PLoS One, v.6, art.e2436, p.1-5, 2011.

DAVID, J.; PIMENTEL, J.C.; FREIRE, R.P.A. Aspecto fenotípico da resistência dos Estafilococos à Clindamicina e Eritromicina. NewsLab, v.70, p.114-115, 2005.

DE GIUSTI, M.; PACIFICO, L.; TUFI, D.; PANERO, A.; BOCCIA, A.; CHIESA, C. Phenotypic detection of nosocomial mecA-positive coagulase-negative staphylococci from neonates. J. Infect. Chemother, v.44, p.351-358, 1999.

EDER, A.F.; GOLDMAN, M. How do I investigate septic transfusion reactions and blood donors with culture-positive platelet donations? Transfusion, v.51, n.8, p.1662-1668, 2011.

EDER, A.F.; DY, B.A.; O’NEILL, E.M. Predicted effect of selectively testing female donors for HLA antibodies to mitigate transfusion-related acute lung injury risk from apheresis platelets. Transfusion, v.56, p.1608-1615, 2016.

FERREIRA, R.; IORIO, N.; MALVAR, K.; NUNES, A.; FONSECA, L.; BASTOS, C.; SANTOS, K.R.N. Coagulasenegative Staphylococci: comparison of phenotypic and genotypic oxacillin sucseptibility tests and evaluation of the Agar screening test by using different concentration of oxacillin. J. Clin. Microbiol., v.41, p.3609-3614, 2003.

FRESCHI, C.R.; CARVALHO, L.F.O.S.; OLIVEIRA, C.J.B. Comparison of DNA-extraction methods and selective enrichment broths on the detection of Salmonella typhimurium in swine feces by Polymerase Chain reaction (PCR). Braz. J. Microbiol., v.36, n.4, p.363-367, 2005.

GAD, G.F.M.; EL-FEKY, M.A.; EL-REHEWY, M.S.; HASSAN, M.A.; ABOLELLA, H.; EL-BAKY, R.M.A. Detection of icaA, icaD genes and biofilm production by Staphylococcus aureus and Staphylococcus epidermidis isolated from urinary tract catheterized patients. J. Infect. Dev. Countries, v.3, n.5, p.342-351, 2009.

GHOSHAL, U.; PRASAD, K.N.; TIWARI, M.S.D.P.; AYYAGARI, A. A comparative evaluation of phenotypic and molecular methods for the detection of oxacillin resistance in coagulase-negative staphylococci. J. Infect. Chemother., v.10, p.86-89, 2004. 
GOODNOUGH, L.T.; SANDER, A.; BRECHER, M.E. Transfusion medicine: looking to the future. Lancet, v.361, p.161-169, 2003.

GRECO, C.; MASTRONARDI, C.; PAGOTTO, F.; MACK, D.; RAMIREZ-ARCOS, S. Assessment of biofilm-forming ability of coagulase-negative staphylococci isolated from contaminated platelet preparations in Canada. Transfusion, v.48, p.969-977, 2008.

HARRISON, E.M.; PATERSON, G.K.; HOLDEN, M.T.; MORGAN, F.J.; LARSEN, A.R.; PETERSEN, A.; LEROY, S.; DE VLIEGHER, S.; PERRETEN, V.; FOX, L.K.; LAM, T.J.; SAMPIMON, O.C.; ZADOKS, R.N.; PEACOCK, S.J.; PARKHILL, J.; HOLMES, M.A. A Staphylococcus xylosus isolate with a new mecC allotype. Antimicrob. Agents Chemother, v.57, p.1524-1528, 2013a.

HARRISON, E.M.; PATERSON, G.K.; HOLDEN, M.T.; BA, X.; ROLO, J.; MORGAN, F.J.; PICHON, B.; KEARNS, A.; ZADOKS, R.N.; PEACOCK, S.J.; PARKHILL, J.; HOLMES, M.A. A novel hybrid SCCmec-mecC region in Staphylococcus sciuri. J. Antimicrob. Chemother., v.69, p.911-918, 2013b.

HUSSAIN, Z.; STOAKES, L.; MASSEY, V.; DIAGRE, D.; FITZGERALD, V.; EL SAYED, S.; LANNIGAN, R. Correlation of oxacilin MIC with mecA gene carriage in coagulase negative staphylococci. J. Clin. Microbiol., v.38, p.752-754, 2000.

HSUEH, J.C.; HO, C.F.; CHANG, S.H.; PAN, F.Z.; CHEN, S.C.; SHI, M.D.; CHIEN, S.T. Blood surveillance and detection on platelet bacterial contamination associated with septic events. Transfus. Med., v.19, p.350-356, 2009.

ITO, T.; OKUMA, K.; MA, X.X.; YUZAWA, H.; HIRAMATSU, $\mathrm{K}$. Insights on antibiotic resistance of Staphylococcus aureus from its whole genome: genomic island SCC. Drug Resist. Updates, v.6, p.41-52, 2003.

ITO, T.; HIRAMATSU, K.; TOMASZ, A.; LENCASTRE, H.; PERRETEN, V.; HOLDEN, M.T.G.; COLEMAN, D.C.; GOERING, R.; GIFFARD, P.M.; SKOV, R.L.; ZHANG, K.; WESTH, H.; O'BRIEN, F.; TENOVER, F.C.; OLIVEIRA, D.C.; BOYLE-VAVRA, S.; LAURENT, F.; KEARNS, A.M.; KREISWIRTH, B.; KO, K.S.; GRUNDMANN, H.; SOLLID, J.E.; JOHN, J.F.J.R.; DAUM, R.; SODERQUIST, B.; BUIST, G. Guidelines for reporting novel mecA gene homologues. Antimicrob. Agents Chemother, v.56, p.49974999, 2012.
JACOBS, M.R.; PALAVECINO, E.; YOMTOVIAN, R. Don’t bug me: the problem of bacterial contamination of blood components challenges and solutions. Transfusion, v.41, p.1331-1334, 2001.

JOHN, M.A.; BURDEN, J.; STUART, J.I.; REYES, R.C.; LANNIGAN, R.; MILBURN, S.; DIAGRE, D.; WILSON, B.; HUSSAIN, Z. Comparison of three phenotypic techniques for detection of methicillin resistance in Staphylococcus spp. reveals a species-dependent performance. J. Antimicrob. Chemother, v.63, n.3, p.493496, 2009.

KEARNS, A.M.; SEIDERS, P.R.; WHEELER, J.; FREEMAN, R.; STEWARD, M. Rapid detection of methicillin-resistant staphylococci by multiplex PCR. J. Hospl. Infect., v.43, p.33-37, 1999.

LANDRUM, M.L.; NEUMANN, C.; COOK, C.; CHUKWUMA, U.; ELLIS, M.W.; HOSPENTHAL, D.R.; MURRAY, C.K. Epidemiology of Staphylococcus aureus blood and skin and soft tissue infections in the US military health system, 2005-2010. JAMA, v.308, p.50-59, 2012.

LAVALLÉE, C; ROULEAU, D.; GAUDREAU, C.; ROGER, M.; TSIMIKLIS, C.; LOCAS, M.C.; GAGNON, S.; DELORME, J.; LABBÉ, A.C. Performance of an agar dilution method and a Vitek 2 Card for detection of inducible clindamycin resistance in Staphylococcus spp. J. Clin. Microbiol., v.48, p.1354-1357, 2010.

LECLERCQ, R. Mechanisms of resistance to macrolides and lincosamides: Nature of the resistance elements and their clinical implications. Clin. Infect. Dis., v.34, p.482-492, 2002.

LI, W.; LIU, L.; CHEN, H.; ZHOU, R. Identification of Streptococcus suis genes preferentially expressed under iron starvation by selective capture of transcribed sequences. FEMS Microbiol. Lett., v.292, p.123-33, 2009.

LIM, D.; STRYNADKA, N.C.J. Structural basis for the beta lactam resistance of PBP2a from methicillin-resistant Staphylococcus aureus. Nat. Struct. Biol., v.9, p.870-876, 2002.

LONCARIC, I.; KÜBBER-HEISS, A.; POSAUTZ, A.; STALDER, G.L.; HOFFMANN, D.; ROSENGARTEN, R.; WALZER, C. Characterization of methicillin-resistant Staphylococcus spp. carrying the mecC gene, isolated from wildlife. J. Antimicrob. Chemother., v.14, p.2222-2225, 2013. 
MARSHALL, S.A.; WILKE, W.W.; PFALLER, M.A.; JONES, R.N. Staphylococcus aureus and coagulase-negative staphylococci from blood stream infections: frequency of occurrence, antimicrobial susceptibility, and molecular $(m e c A)$ characterization of oxacillin resistance in the SCOPE program. Diagn. Microbiol. Infect. Dis., v.30, p.205-214, 1998.

MARTÍNEZ, F.; TARRAND, J.; LICHTIGER, B. Impact on patient outcome following transfusion of bacterially contaminated platelets: the M.D. Anderson Center experience. Am. J. Clin. Pathol., v.134, p.207-212, 2010.

MARTINI, R.; HORNER, R.; RODRIGUES, M.A.; KEMPFER, C.A.; TIZOTTI, M.K.; RAYZLAFF, V. Bacteriological analysis of platelets and cases of septic reactions associated with transfusion of contaminated samples. Transfus. Apher. Sci., v.47, p.313-318, 2012.

MATSUOKA, M.; JÁNOSI, L.; ENDOU, K.; NAKAJIMA, Y. Cloning and sequences of inducible and constitutive macrolide resistance genes in Staphylococcus aureus that correspond to an $\mathrm{ABC}$ transporter. FEMS Microbiol. Lett., v.181, p.91-100, 1999.

MATSUOKA, M.; INOUE, M.; NAKAJIMA, Y.; ENDO, Y. New erm Gene in Staphylococcus aureus clinical isolates. Antimicrob. Agents Chemother, v.46, p.211-215, 2012.

MELO, M.A.C.; MONTEIRO, R.C.S.; VIEIRA, A.B.R.; BRAZÃO, M.A.B.; VIEIRA, J.M.S. Bactérias isoladas de ponta de cateter venoso central e suscetibilidade antimicrobiana em um hospital público de Belém-PA. Rev. Bras. Anal. Clin., v.39, p.115-118, 2007.

MOHANASOUNDARAM, K.M.; LALITHA, M.K. Comparison of phenotypic versus genotypic methods in the detection of methicillin resistance in Staphylococcus aureus. Indian J. Med. Res., v.127, p.78-84, 2008.

NAKAJIMA, Y. Mechanisms of bacterial resistance to macrolide antibiotics. J. Infect. Chemother, v.5, p.61-74, 1999.

NOGUEIRA, C.A.M.; MOMESSO, C.A.S.; MACHADO, R.L.D.; ALMEIDA, M.T.G.; ROSSIT, A.R.B. Desempenho de kits comerciais e protocolos laboratoriais para a extração de DNA genômico bacteriano. Rev. Panam. Infectol., v.6, p.35-38, 2004.
PAIM, T.G.S.; CANTARELLI, V.V.; D’AZEVEDO, P.A. Performance of the Vitek 2 system software version 5.03 in the bacterial identification and antimicrobial susceptibility test: evaluation study of clinical and reference strains of Gram-positive cocci. Rev. Soc. Bras. Med. Trop., v.47, p.377-381, 2014.

PALAZZO, I.C.V.; DARINI, A.L.C. Evaluation of methods for detecting oxacillin resistance in coagulase-negative staphylococci including cefoxitin disc diffusion. FEMS Microbiol. Lett., v.257, p.299-305, 2006.

PATERSON, G.K.; HARRISON, E.M.; HOLMES, M.A. The emergence of mecC methicillin-resistant Staphylococcus aureus. Trends in Microbiol., v.22, p.42-47, 2014.

RIGATTI, F.; TIZOTI, M.K.; HÖRNER, R.; DOMINGUES, V.O.; MARTINI, R.; MAYER, L.E.; KHUN, F.T.; FRANÇA, C.A.; COSTA, M.M. Bacteremias por Staphylococcus coagulase negativos oxacilina resistentes em um hospital escola na cidade de Santa Maria, Estado do Rio Grande do Sul. Rev. Soc. Bras. Med. Trop., v.43, p.686-690, 2010.

ROBERTS, M.C.; SUTCLIFFE, J.; COURVALIN, P.; JENSEN, L.B.; ROOD, J.; SEPPALA, H. Nomenclature for macrolide-lincosamide-streptogramin B resistance determinants. Antimicrob. Agents Chemother, v.4, p.28232830, 1999.

ROSSI, F.; ANDREAZZI, D.B. Resistência bacteriana: interpretando o antibiograma. São Paulo: Atheneu, 2005. cap.4, p.27-61.

RUZICKA, F.; HOLÁ, V.; VOTAVA, M.; TEJKALOVÁ, R.; HORVÁT, R.; HEROLDOVÁ, M.; WOZNICOVÁ, V. Biofilm detection and the clinical significance of Staphylococcus epidermidis isolates. Folia Microbiol., v.49, p.596-600, 2004.

SAPINO, B.; MAZZUCATO, S.; SOLINAS, M.; GION, M.; GRANDESS, S. Comparison of different methods for determining beta-lactam susceptibility in Pseudomonas aeruginosa. New Microbiol., v.35, p.491-494, 2012.

SCHEFFER, M.C. Genotipagem e pesquisa de metalobeta-lactamases em isolados clínicos de Pseudomonas aeruginosa resistentes aos carbapenêmicos. Curitiba, 2008. 117p. Dissertação (Mestrado em Microbiologia, Parasitologia e Patologia) - Universidade Federal do Paraná. 
SHORE, A.C.; DEASY, E.C.; SLICKERS, P.; BRENNAN, G.; O'CONNELL, B.; MONECKE, S.; EHRICHT, R.; COLEMAN, D.C. Detection of Staphylococcal cassette chromosome mec type XI carrying highly divergent mecA, mecI, mecR1, blaZ, and ccr genes in human clinical isolates of clonal complex 130 Methicillin-resistant Staphylococcus aureus. Antimicrob. Agents Chemother, v.55, p.3765-3773, 2011

STOLL, B.J.; HANSEN, N.; FANAROFF, A.A.; WRIGHT, L.L. Late-onset sepsis in very low birth weight neonates: the experience of the NICHD Neonatal Research Network. Pediatric, v.110, p.285-291, 2002.

TOMASZ, A.; DRUGEON, H.B.; LENCASTRE, H.M.; JABES, D.; MCDOUGAL, L.; BILLE, J. New mechanism for methicillin-resistance in S. aureus: clinical isolates that lack the PBP2a gene and contain normal penicilinbindig proteins with modified penicilin-binding capacity. Antimicrob. Agents Chemother, v.33, p.1869-1874, 1989.
TSUBAKISHITA, S.; KUWAHARA-ARAI, K.; SASAKI, T.; HIRAMATSU, K. Origin and molecular evolution of the determinant of methicillin resistance in staphylococci. Antimicrob. Agents Chemother, v.54, n.10, p.4352-4359, 2010.

VASCONCELOS, E.; SEGHATCHIAN, J. Bacterial contamination in blood components and preventative strategies: an overview. Transf. Apher. Sci., v.31, p.155$163,2004$.

WALTHER-WENKE, G.; SCHREZENMEIER, H.; DEITENBECK, R.; GEIS, G.; BURKHART, J.; HÖCHSMANN, B.; SIREIS, W.; SCHMIDT, M.; SEIFRIED, E.; GEBAUER, W.; LIEBSCHER, U.M.; WEINAUER, F.; MÜLLER, T.H. Screening of platelet concentrates for bacterial contamination: spectrum of bacteria detected, proportion of transfused units, and clinical follow-up. Ann. Hematol., v.89, p.83-91, 2010.

Received for publication on $05^{\text {th }}$ October 2015 Accepted for publication on $06^{\text {th }}$ October 2016 